\title{
Promising Assays for Examining a Putative Role of Ribosomal Heterogeneity in COVID-19 Susceptibility and Severity
}

\author{
Yih-Horng Shiao (D)
}

Citation: Shiao, Y.-H. Promising Assays for Examining a Putative Role of Ribosomal Heterogeneity in COVID-19 Susceptibility and Severity. Life 2022, 12, 203. https:/ / doi.org/ $10.3390 /$ life12020203

Academic Editor: Daniele Focosi

Received: 5 January 2022

Accepted: 27 January 2022

Published: 28 January 2022

Publisher's Note: MDPI stays neutral with regard to jurisdictional claims in published maps and institutional affiliations.

Copyright: (C) 2022 by the author. Licensee MDPI, Basel, Switzerland. This article is an open access article distributed under the terms and conditions of the Creative Commons Attribution (CC BY) license (https:// creativecommons.org/licenses/by/ $4.0 /)$.
US Patent Trademark Office, Department of Commerce, Alexandria, VA 22314, USA; yihhorng@aol.com

\begin{abstract}
The heterogeneity of ribosomes, characterized by structural variations, arises from differences in types, numbers, and/or post-translational modifications of participating ribosomal proteins (RPs), ribosomal RNAs (rRNAs) sequence variants plus post-transcriptional modifications, and additional molecules essential for forming a translational machinery. The ribosomal heterogeneity within an individual organism or a single cell leads to preferential translations of selected messenger RNA (mRNA) transcripts over others, especially in response to environmental cues. The role of ribosomal heterogeneity in SARS-CoV-2 coronavirus infection, propagation, related symptoms, or vaccine responses is not known, and a technique to examine these has not yet been developed. Tools to detect ribosomal heterogeneity or to profile translating mRNAs independently cannot identify unique or specialized ribosome(s) along with corresponding mRNA substrate(s). Concurrent characterizations of RPs and/or rRNAs with mRNA substrate from a single ribosome would be critical to decipher the putative role of ribosomal heterogeneity in the COVID-19 disease, caused by the SARS-CoV-2, which hijacks the host ribosome to preferentially translate its RNA genome. Such a protocol should be able to provide a high-throughput screening of clinical samples in a large population that would reach a statistical power for determining the impact of a specialized ribosome to specific characteristics of the disease. These characteristics may include host susceptibility, viral infectivity and transmissibility, severity of symptoms, antiviral treatment responses, and vaccine immunogenicity including its side effect and efficacy. In this study, several state-of-the-art techniques, in particular, chemical probing of ribosomal components or rRNA structures, proximity ligation to generate rRNA-mRNA chimeras for sequencing, nanopore gating of individual ribosomes, nanopore RNA sequencing and/or structural analyses, single-ribosome mass spectrometry, and microfluidic droplets for separating ribosomes or indexing rRNAs/mRNAs, are discussed. The key elements for further improvement and proper integration of the above techniques to potentially arrive at a high-throughput protocol for examining individual ribosomes and their mRNA substrates in a clinical setting are also presented.
\end{abstract}

Keywords: translation machinery; SARS-CoV-2; COVID-19; ribosomes; ribosomal heterogeneity; ribosomal RNAs; ribosomal proteins; assays for RNA sequence and structure; assays for proteins

\section{Interaction of SARS-CoV-2 with Ribosome}

The severe acute respiratory syndrome-coronavirus-2 (SARS-CoV-2) is a single-stranded RNA virus and relies on host translational machinery to synthesize non-structural proteins (NSP1 to NSP16) and structural proteins (envelope, spike, membrane, and nucleocapsid). This allows the virus to prioritize its life cycle by evading and disrupting the host defense mechanisms [1-3]. Interactions of viral proteins and RNAs with host ribosomal translational machinery have been extensively characterized in cultured cells by chemical and/or physical cross-linking strategies followed by mass spectrometry and/or RNA-sequencing. One such study showed that NSP1 binds to a helix 18 region of the 18S ribosomal RNA (rRNA) including the G626 nucleotide near the messenger RNA (mRNA) entry channel. This potentially blocks the $40 \mathrm{~S}$ ribosomal subunit to scan host mRNA and the recruitment of transfer RNAs (tRNAs) to the active 80S ribosome. Conversely, NSP8 attacks the 28S rRNA at the expansion segment ES27 of the $60 \mathrm{~S}$ ribosomal subunit and may interfere with the 
exit of newly translated protein [4]. NSP1 upon binding to the 40S subunit also accelerates degradation of cellular mRNAs but protects viral RNAs containing a $5^{\prime}$-leader that is added during negative-strand synthesis [5]. In addition, NSP1 modulates ribosomal preinitiation complex, which contains eukaryotic translation initiation factors (EIFs) and the initiator tRNA to refrain cap-dependent host mRNAs from binding to the $40 \mathrm{~S}$ subunit [6]. Viral RNA physically interacts with translational machinery, including several ribosomal proteins of the cytosolic $80 \mathrm{~S}$ ribosome, translation initiation factors (such as EIF3B, 4H, 4B, 3F, and A3), and mitochondrial $12 \mathrm{~S}$ and $16 \mathrm{~S}$ rRNAs [7]. These and other ribosomal components of the small $40 S$ or large 50S ribosome subunit, translation initiation complex, and translation elongation factor have been also consistently detected to form complexes with SARS-CoV-2 RNA [8-10].

Selected mutations of the SARS-CoV-2 RNA have been shown to influence the efficacy of programmed -1 ribosomal frameshift via pseudoknot structure that determines the final production of either viral pp1a or pplab polypeptide from the corresponding open reading frame 1a (ORF1a) or ORF1b [11]. Such pseudoknot is embedded within a frameshift element-arch as a result of $\mathrm{a} \approx 1.5-\mathrm{kb}$ long RNA-RNA interaction of the viral genome [12]. The pseudoknot-mediated programmed -1 ribosomal frameshift activity also depends on the proper folding of the viral genome, which is supported by a computational prediction of 98 co-variant base pairs out of 200,621 SARS-CoV-2 strains in comparison with reference sequence [13]. This suggests that the efficiency of frameshift may be diverse among viral strains. Moreover, those mechanisms of direct interactions with ribosomes, extracellular binding of spike protein to ACE2 receptor has been shown to trigger phosphorylation and release of the ribosomal L13a protein from active translating ribosome [14]. SARS-CoV2 also stoichiometrically reduces the cellular RNA-binding proteins, including EIF3 (D, E, and L) and EIF2S1 in infected cells [15]. Proper co-translational folding of the RNAdependent RNA polymerase NSP12, mediated by pausing of ribosome at rare codons, is essential for producing active enzyme. It may have an implication for the natural selection of SARS-CoV-2 variants [16].

\section{Heterogeneity of Ribosome}

One direct evidence of ribosomal heterogeneity comes from ribosomopathy, caused by defective RPs and/or rRNAs. In the Diamond-Blackfan Anemia (DBA), ribosomes with deficient ribosomal protein RPS26 preferentially translate mRNAs from stress-response pathway while those having proficient RPS26 recognize mRNAs with defined Kozak sequence [17]. In addition, the RPL5 genetic variant rs376208311 showed less calculated ribosomal loads compared with wild-type sequence, presumably leading to stoichiometric reduction of RPL5 protein in the ribosomes and DBA cells [18]. In mouse embryonic stem cells, a lower abundance of several ribosomal proteins in polysomes compared with free nonactive ribosomes was detected. Further ribosomal profiling analysis revealed that ribosomes categorized by the presence or absence of tagged RPL10A or RPS25 display differential binding preference to distinct sets of transcripts [19]. Using such approach of tagging ribosomal proteins endogenously, several ribosome-associated proteins and preferential transcript substrates also have been individually identified [20]. A genetic approach by coupling of mammalians 18S rRNA expansion segment ES9 into yeast ribosome also selectively recruits a set of transcripts containing internal ribosome entry site (IRES)-like element and facilitates cap-independent translation [21]. In the zebrafish model, replacement of maternal rRNAs with somatic rRNAs is observed during embryogenesis. This shifts from the preferential binding of $18 \mathrm{~S}$ expansion segment ES3 over ES6 onto maternally expressed mRNAs to binding of ES6 over ES3 onto somatically expressed mRNAs in silico assay [22]. Other examples of rRNA sequence variants and/or modifications, or ribosomal protein paralogs, stoichiometry, and/or modifications that potentially contribute to ribosomal heterogeneity, have been recently reviewed by Li et al. [23] and Gay et al. [24]. The putative role of ribosomal heterogeneity in diseases or physiological protein biogenesis requires further investigation. 


\section{Detection of Ribosomal Heterogeneity}

\subsection{Chemical Probing of Ribosomal Components or rRNA Structures}

Ribosomal proteins and rRNAs form complexes with other initiation and elongation partners, such as EIFs and tRNAs, to perform translational activities. To preserve the initial secondary or tertiary structures, crosslinking agents are commonly applied before subsequent sample processing. The following techniques in Table 1 have been used to identify partner molecules of ribosomal proteins and/or rRNAs. The psoralen and its chemical analogs intercalate into double-stranded nucleic acids and form covalent bonds, preferentially with pyrimidines, upon UV irradiation at $365 \mathrm{~nm}$, in which the covalent bonds are broken or reversed by irradiation at $254 \mathrm{~nm}$ before subsequent enzymatic reactions [25]. The crosslinking targets of other chemicals or UV irradiation can be found in the corresponding references below.

Table 1. Chemical and/or physical probing for interactions among RNAs and proteins.

\begin{tabular}{|c|c|c|c|c|}
\hline Technique & Chemical Probe & Irradiation & Probing Structure $^{a}$ & Ref. \\
\hline $\begin{array}{c}\text { SPLASH (Sequencing } \\
\text { ofpsoralen crosslinked, } \\
\text { ligated, and selected hybrids) }\end{array}$ & Psoralen-PEG3-Biotin & UV-A (365 nm) & $\begin{array}{c}\text { rRNA-rRNA, } \\
\text { mRNA-rRNA, } \\
\text { snRNA-rRNA, } \\
\text { snoRNA-rRNA, and } \\
\text { mRNA-mRNA }\end{array}$ & [25] \\
\hline $\begin{array}{l}\text { COMRADES (Cross-linking of matched } \\
\text { RNAs and deep sequencing) }\end{array}$ & $\begin{array}{l}\text { Psoralen-triethylene } \\
\text { glycol azide }\end{array}$ & UV-A (365 nm) & $\begin{array}{l}\text { rRNA-rRNA and } \\
\text { interaction of viral } \\
\text { RNA with } \\
\text { cellular RNAs }\end{array}$ & [26] \\
\hline $\begin{array}{l}\text { SHAPE-JuMP (Selective } 2 \text { '-hydroxyl } \\
\text { acylation, primer extension and } \\
\text { juxtaposed merged pairs) }\end{array}$ & Trans bis-isatoic anhydride & & RNA-RNA & [27] \\
\hline $\begin{array}{c}\text { LIGR-seq (Ligation of interacting } \\
\text { RNA and high-throughput } \\
\text { Sequencing) }\end{array}$ & $\begin{array}{l}4^{\prime} \text {-aminomethyltrioxalen } \\
(\mathrm{AMT})\end{array}$ & UV-A (365 nm) & $\begin{array}{l}\text { snRNA-snRNA, } \\
\text { snoRNA-mRNA, and } \\
\text { rRNA-rRNA }\end{array}$ & [28] \\
\hline $\begin{array}{l}\text { hiCLIP (RNA hybrid, } \\
\text { individual-nucleotide resolution, UV } \\
\text { crosslinking and immunoprecipitation }\end{array}$ & Formaldehyde & UV-C (254 nm) & $\begin{array}{l}\text { Protein-protein and } \\
\text { RNA-protein } \\
\text { RNA-protein }\end{array}$ & [29] \\
\hline $\begin{array}{l}\text { XL-MS (Crosslinking/ } \\
\text { mass spectrometry) }\end{array}$ & $\begin{array}{l}\text { disuccinimidyl } \\
\text { diacetic urea }\end{array}$ & & Protein-protein & {$[30]$} \\
\hline $\begin{array}{l}\text { PTex (Phenol-Toluol extraction) } \\
\text { crosslinked RNA-protein }\end{array}$ & $\begin{array}{l}\text { With/without } \\
\text { 2-iminothiolane }\end{array}$ & UV-C (254 nm) & RNA-protein & [31] \\
\hline $\begin{array}{l}\text { Chemically Reversible } \\
\text { Acylation }\end{array}$ & $\begin{array}{l}\text { bis-nicotinic azide } \\
\text { reversible interaction }\end{array}$ & & RNA-RNA & [32] \\
\hline $\begin{array}{c}\text { PARIS } 2 \text { (Psoralen analysis of RNA } \\
\text { interactions and structures, } \\
\text { second version) }\end{array}$ & $\begin{array}{c}\text { amotosalen or } \\
4^{\prime} \text {-aminomethyl trioxalen }\end{array}$ & UV-A (365 nm) & $\begin{array}{l}\text { rRNA-rRNA, } \\
\text { mRNA-rRNA, and } \\
\text { snoRNA-rRNA }\end{array}$ & [33] \\
\hline $\begin{array}{l}\text { CLASH (Crosslinking, ligation, and } \\
\text { sequencing of hybrids) }\end{array}$ & & UV-C (254 nm) & $\begin{array}{l}\text { snoRNA-rRNA and } \\
\text { RNA-protein }\end{array}$ & [34] \\
\hline $\begin{array}{l}\text { XRNAX (Protein-Crosslinked } \\
\text { RNA Extraction) }\end{array}$ & & UV-C (254 nm) & RNA-protein & [35] \\
\hline $\begin{array}{l}\text { RIC-seq (RNA in situ } \\
\text { conformational sequencing) }\end{array}$ & Formaldehyde & & $\begin{array}{l}\text { rRNA-rRNA, } \\
\text { snoRNA-rRNA, } \\
\text { rRNA-mRNA, and } \\
\text { snoRNA-mRNA }\end{array}$ & [36] \\
\hline $\begin{array}{l}\text { In situ CLMS (In situ cross-linking } \\
\text { and mass spectrometry) }\end{array}$ & $\begin{array}{c}\text { Formaldehyde } \\
\text { Disuccinimidyl suberate }\end{array}$ & & $\begin{array}{l}\text { Protein-protein } \\
\text { Protein-protein }\end{array}$ & [37] \\
\hline
\end{tabular}

${ }^{a}$ snRNA: small nuclear RNA; snoRNA: small nucleolar RNA. 
It is not possible to list every published technique in this study. Other chemicals to target specific sites of nucleic bases, ribose, and amino acids have been also applied to capture the interactions among RNAs and proteins. Readers are encouraged to check out some excellent review articles to acquaint other related methods and tips for further improvement [38-43].

\subsection{Proximity Ligation to Generate $r R N A-m R N A$ Chimeras for Sequencing}

Proximity ligation has been widely used to determine RNA secondary structures by probing the RNA-RNA interactions, including the generation of rRNA-mRNA chimeras by joining the two RNAs from the same ribosome, as provided in some techniques listed in Table $1[25,28,33,34,36]$. Such techniques may potentially be used to identify individual rRNA sequence variants and corresponding mRNA substrates in a single-molecule RNA sequencing read. The information of the chimerical sequences can then be interrogated to detect specialized ribosomes, characterized by unique rRNA single-nucleotide and/or short-tandem repeat variants, along with their translating mRNAs. The longer the rRNA component of the chimera is obtained, the higher the chance is to detect rRNA sequence variants. The mRNA component only requires a short length for sequence identification. The protocol of proximity ligation may start with or without crosslinking followed by fragmentation or purification/enrichment before fragmentation, ligation or purification/enrichment before ligation, and additional round(s) of purification/enrichment before complementary DNA (cDNA) library preparation, and lastly next-generation high-throughput sequencing (next-gen Seq) plus bioinformatic analyses. The following methods listed in Table 2 are selected to represent diverse designs of protocols for generating chimeric RNAs, specific cDNA library, and polymerase chain reaction (PCR)-amplified double-stranded products for sequence analyses. The comparison below is intended to highlight the mechanism behind each step, not to create a preference list for the readers.

Table 2. Comparison of selected proximity ligation protocols.

\begin{tabular}{|c|c|c|c|c|c|c|}
\hline Method & $\begin{array}{c}\text { Crosslink } \\
\text { (for Purification } \\
\text { or Enrichment) }\end{array}$ & $\begin{array}{c}\text { Fragmentation } \\
\text { (for Purification or } \\
\text { Enrichment) }\end{array}$ & $\begin{array}{c}\text { Ligation } \\
\text { (for Purification or } \\
\text { Enrichment) }\end{array}$ & $\begin{array}{c}\text { Library } \\
\text { Preparation and } \\
\text { Sequencing }\end{array}$ & Cautions $^{\text {a }}$ & Ref. \\
\hline SPLASH & $\begin{array}{l}\text { Psoralen-PEG3- } \\
\text { Biotin/UV-A } \\
\text { (Trizol RNA } \\
\text { extraction) }\end{array}$ & $\begin{array}{c}\mathrm{MgCl}_{2}, \mathrm{pH} 8.3, \\
95{ }^{\circ} \mathrm{C} \text { (urea gel to } \\
\text { obtain } 90-110 \\
\text { nucleotides [nts] } \\
\text { followed by } \\
\text { streptavidin bead } \\
\text { purification) }\end{array}$ & $\begin{array}{l}\text { T4 PNKinase } \\
\text { followed by T4 } \\
\text { RNA ligase I } \\
\text { (Trizol) }\end{array}$ & $\begin{array}{l}\text { Crosslink-reversal } \\
\text { by UV-C, 3'adaptor } \\
\text { ligation, urea gel to } \\
\text { obtain } 110-130 \text { nts, } \\
\text { cDNA synthesis } \\
\text { and circularization, } \\
\text { PCR (200-300 bp), } \\
\text { and next-gen Seq }\end{array}$ & $\begin{array}{l}\text { Low cell } \\
\text { permeability } \\
\text { of } \\
\text { biopsoralen; } \\
\text { UV-C damage } \\
\text { to RNAs }\end{array}$ & [25] \\
\hline CLASH & $\begin{array}{l}\text { UV-C (IgG bead } \\
\text { RNAs-protein } \\
\text { complex } \\
\text { purification after } \\
\text { cell lysis) }\end{array}$ & $\begin{array}{l}\text { RNase A and T1 } \\
\text { single-stranded } \\
\text { endo-RNase } \\
\text { (Nickel bead to } \\
\text { bind His-tag } \\
\text { snoRNP) }\end{array}$ & $\begin{array}{c}\text { On-bead } \\
3^{\prime} \text {-phosphate } \\
\text { removal, followed } \\
\text { by } 3^{\prime} \text { and } 5^{\prime} \\
\text { adaptor ligation by } \\
\text { T4 RNA ligase (gel } \\
\text { isolation of the } \\
\text { RNA-protein } \\
\text { complex) }\end{array}$ & $\begin{array}{c}\text { Proteinase K } \\
\text { digestion, RNA } \\
\text { extraction, cDNA } \\
\text { synthesis, PCR } \\
\text { (>60 bp), TA } \\
\text { cloning, } \\
\text { next-gen Seq }\end{array}$ & $\begin{array}{l}\text { Detection of } \\
\text { interaction for } \\
\text { a specific } \\
\text { protein }\end{array}$ & {$[34,44]$} \\
\hline
\end{tabular}


Table 2. Cont.

\begin{tabular}{|c|c|c|c|c|c|c|}
\hline Method & $\begin{array}{c}\text { Crosslink } \\
\text { (for Purification } \\
\text { or Enrichment) }\end{array}$ & $\begin{array}{c}\text { Fragmentation } \\
\text { (for Purification or } \\
\text { Enrichment) }\end{array}$ & $\begin{array}{c}\text { Ligation } \\
\text { (for Purification or } \\
\text { Enrichment) }\end{array}$ & $\begin{array}{c}\text { Library } \\
\text { Preparation and } \\
\text { Sequencing }\end{array}$ & Cautions $^{a}$ & Ref. \\
\hline $\begin{array}{l}\text { RPL (RNA } \\
\text { proximity } \\
\text { ligation) }\end{array}$ & None & $\begin{array}{c}\text { Endogenous RNase } \\
\text { for yeast cell; } \\
\text { RNase A and T1 for } \\
\text { human cell }\end{array}$ & $\begin{array}{l}\text { T4 PNKinase } \\
\text { followed by T4 } \\
\text { RNA ligase I } \\
\text { (Trizol) }\end{array}$ & $\begin{array}{c}\text { Modified Illumina } \\
\text { TruSeq RNA kit } \\
\text { (RNA } \\
\text { fragmentation, } \\
\text { cDNA synthesis, } \\
\text { and PCR) and } \\
\text { pair-end 80/101-bp } \\
\text { reads in a } \\
\text { next-gen Seq }\end{array}$ & $\begin{array}{l}\text { Low } \\
\text { abundance of } \\
\text { mRNAs }\end{array}$ & [45] \\
\hline LIGR-seq & $\begin{array}{c}\text { AMT/UV-A } \\
\text { (Trizol/DNase I } \\
\text { treatment) }\end{array}$ & $\begin{array}{l}\text { S1 endonuclease } \\
\text { after rRNA } \\
\text { depletion (phenol- } \\
\text { chloroform } \\
\text { extraction) }\end{array}$ & $\begin{array}{l}\text { circRNA ligase } \\
\left(3^{\prime}-5^{\prime} \text { exo-RNase } \mathrm{R}\right. \\
\text { digestion followed } \\
\text { by phenol and } \\
\text { chloroform } \\
\text { extraction) }\end{array}$ & $\begin{array}{c}\text { Crosslink-reversal } \\
\text { by UV-C, } \\
\text { precipitation of } \\
\text { RNAs, modified } \\
\text { Clontech } \\
\text { SMARTER library } \\
\text { prep, gel isolation } \\
\text { of }>200 \text { bp products } \\
\text { for next-gen Seq }\end{array}$ & $\begin{array}{l}\text { Reduction of } \\
\text { rRNA due to } \\
\text { depletion step }\end{array}$ & [28] \\
\hline COMRADES & $\begin{array}{c}\text { Psoralen- } \\
\text { triethylene glycol } \\
\text { azide/UV-A } \\
\text { (Qiagen RNeasy } \\
\text { lysis / } \\
\text { purification, } \\
\text { followed by } \\
\text { on-bead isolation } \\
\text { with antisense } \\
\text { probes) }\end{array}$ & $\begin{array}{c}\text { RNase III } \\
\text { db-stranded } \\
\text { endo-RNase (Zymo } \\
\text { RNA Concentrator, } \\
\text { chemical linking of } \\
\text { biotin-alkyne to } \\
\text { azide on } \\
\text { crosslinked RNAs } \\
\text { and on-bead } \\
\text { isolation) }\end{array}$ & $\begin{array}{c}\text { RNA ligase } 1 \\
\text { (Zymo RNA Clean } \\
\text { and Concentrator) }\end{array}$ & $\begin{array}{l}\text { Crosslink-reversal } \\
\text { by UV-C, } 5^{\prime} \text { - and } \\
\text { 3'-adaptors ligation, } \\
\text { cDNA synthesis, } \\
\text { PCR, and on-gel } \\
\text { size selection for } \\
\text { pair-end 150-bp } \\
\text { reads in a } \\
\text { next-gen Seq }\end{array}$ & $\begin{array}{l}\text { Detection of } \\
\text { interaction for } \\
\text { a specific } \\
\text { RNA }\end{array}$ & [12] \\
\hline RIC-seq & $\begin{array}{c}\text { Formaldehyde } \\
\text { (quenched, } \\
\text { washed, and cell } \\
\text { permeabiliza- } \\
\text { tion) }\end{array}$ & $\begin{array}{c}\text { In-cell micrococcal } \\
\text { endo-exonuclease } \\
\text { digestion (cell } \\
\text { wash, } \\
\text { 3'dephosphorylation } \\
\text { of fragmented } \\
\text { RNAs, ligation of } \\
\text { pCp-biotin, } \\
\text { removal of } \\
\text { 3'phosphate of } \\
\text { pCp-ligated RNAs, } \\
\text { cell wash, } \\
\text { 5'phosphorylation, } \\
\text { and cell wash) }\end{array}$ & $\begin{array}{c}\text { In-cell T4 RNA } \\
\text { ligase ligation (cell } \\
\text { wash and lysis by } \\
\text { proteinase } \mathrm{K} \text {, Trizol } \\
\text { extraction, } \\
\text { DNase I treated, } \\
\text { fragmentation of } \\
{\text { RNA in } \mathrm{MgCl}_{2} \text { at }}^{\circ} \mathrm{C} \text {, on-bead } \\
94^{\circ} \text { enrichment of } \\
\text { biotin-labeled RNA } \\
\text { chimeras, and } \\
\text { phenol and } \\
\text { chloroform } \\
\text { extraction) }\end{array}$ & $\begin{array}{c}\text { Strand-specific } \\
\text { cDNA synthesis } \\
\text { (hexamers to } \\
\text { generate the first } \\
\text { strand, RNase } \\
\text { H-truncated RNA } \\
\text { strand as primer to } \\
\text { yield a } \\
\text { dUTP-containing } \\
\text { second strand, } \\
3^{\prime} \text { adenylation, } \\
\text { ligation of } 3^{\prime} \text { and } \\
5^{\prime} \text { adaptors, and } \\
\text { digestion of the } \\
\text { dUTP strand), PCR } \\
\text { and on-gel isolation } \\
\text { of } 200-450 \text { bp } \\
\text { products for } \\
\text { next-gen Seq with } \\
\text { pair-end reads of } \\
\text { about } 260 \text { bp }\end{array}$ & $\begin{array}{c}\text { Enriched } \\
\text { interactions: } \\
\text { mRNA- } \\
\text { mRNA > } \\
\text { ncRNA- } \\
\text { ncRNA > } \\
\text { mRNA- } \\
\text { ncRNA > } \\
\text { pseudogene- } \\
\text { pseudogene } \\
\text { (ncRNA } \\
\text { includes } \\
\text { lncRNA, } \\
\text { snoRNA, and } \\
\text { eRNA) }\end{array}$ & [36] \\
\hline
\end{tabular}


Table 2. Cont.

\begin{tabular}{|c|c|c|c|c|c|c|}
\hline Method & $\begin{array}{l}\text { Crosslink } \\
\text { (for Purification } \\
\text { or Enrichment) }\end{array}$ & $\begin{array}{c}\text { Fragmentation } \\
\text { (for Purification or } \\
\text { Enrichment) }\end{array}$ & $\begin{array}{c}\text { Ligation } \\
\text { (for Purification or } \\
\text { Enrichment) }\end{array}$ & $\begin{array}{c}\text { Library } \\
\text { Preparation and } \\
\text { Sequencing }\end{array}$ & Cautions $^{a}$ & Ref. \\
\hline PARIS2 & $\begin{array}{c}\text { Water-soluble } \\
\text { amotosalen/UV- } \\
\text { A (cell or tissue } \\
\text { wash, cell lysis } \\
\text { with Guanidine } \\
\text { Isothiocyanate } \\
\text { followed by } \\
\text { Proteinase K and } \\
\text { DNase digestions } \\
\text { with phenol/ } \\
\text { isopropanol } \\
\text { extraction after } \\
\text { each digestion) }\end{array}$ & $\begin{array}{l}\text { ShortCut RNase III } \\
\text { double-stranded } \\
\text { endoribonuclease } \\
\text { (RNA precipitation } \\
\text { and 2D urea-gel to } \\
\text { isolate RNA } \\
\text { fragments of } 50 \text { nts } \\
\text { or higher) }\end{array}$ & $\begin{array}{c}\text { T4 RNA ligase } 1 \\
\text { (RNA } \\
\text { precipitation) }\end{array}$ & $\begin{array}{l}\text { Crosslink-reversal } \\
\text { with little RNA } \\
\text { damage (UV-C plus } \\
\text { acridine orange } \\
\text { singlet quencher), } \\
\text { 3'adaptor ligation, } \\
\text { SuperScript-IV to } \\
\text { generate cDNAs, } \\
\text { RNase H/A/T1 to } \\
\text { remove RNAs, } \\
\text { CircLigase }{ }^{\mathrm{TM}} \mathrm{II} \text { to } \\
\text { circularize cDNAs, } \\
\text { PCR, and on-gel } \\
\text { isolation of } 175 \text { bp } \\
\text { or higher for } \\
\text { next-gen Seq }\end{array}$ & $\begin{array}{c}\text { Low } \\
\text { efficiency of } \\
\text { proximity } \\
\text { ligation by } \\
\text { T4 RNA ligase } \\
\text { ( } \approx 10 \% \text { gapped } \\
\text { or chimeric } \\
\text { reads); bias } \\
\text { toward } \\
\text { uridine } \\
\text { crosslink by } \\
\text { AMT or } \\
\text { amotosalen }\end{array}$ & [33] \\
\hline
\end{tabular}

a lncRNA: long-noncoding RNA; snoRNA: small nucleolar RNA; eRNA: enhancer RNA.

As exemplified above, the available proximity ligation approaches only decipher short chimeric sequences of up to a hundred nucleotides. They limit their applications to identify sequence variants across several hundred to thousands of nucleotides within the 18S, 28S, 5.8S, and 5S rRNAs. Close interactions between rRNAs and mRNAs have been observed in several organisms. The base-pairing of 5'leader of cap-dependent Gtx or FGF2 mRNA to helix 26 of mouse $18 \mathrm{~S}$ rRNA has been detected by sequence-specific translational assay or a masking assay with antisense oligonucleotides targeting the mRNA or rRNA [46]. A site-directed mutagenesis examination of the core IRES structure of the IGF1R mRNA shows a near-perfect Watson-Crick complementarity of the IRES to the G961 loop (helix 23b) of the human $18 \mathrm{~S}$ rRNA in cultured cells [47]. A region around the AUG start codon of the mouse histone $H 4$ mRNA forms a folded structure next to the tip of, and a base-pairing with, the $18 \mathrm{~S}$ rRNA helix 16 in rabbit ribosome, examined by cryo-electron microscopy (cryo-EM) [48]. Base-pairing of hepatitis C virus (HCV) IRES with the $18 \mathrm{~S}$ rRNA helix 26 is also demonstrated in mouse cells expressing a recombinant 18S rRNA [49]. In a screening of RNA-RNA interactions in human cells, specific crosslinks of mRNAs to the $18 \mathrm{~S}$ rRNA at helix 18 and 26 regions have been observed [33]. A direct binding of Hoxa9 IRES-like element to expansion segment ES9S of the 18S rRNA is detected in ES9S-humanized yeast ribosome by cryo-EM [50]. Furthermore, the AUG codon-anticodon of an uncapped unstructured model mRNA has been localized to the vicinity of the $18 \mathrm{~S}$ rRNA at nucleotides C1637 and U1191 with additional G1150 and G904 adjacent to position -1 and -3 of the mRNA, respectively [51]. Although SARS-CoV-2 also utilizes cap-dependent translation initiation, an IRES-like upstream opened reading frame (uORF) structure has been identified across 28 SARS-CoV-2 variants [52]. It appears that the $5^{\prime}$ untranslated region ( $\left.5^{\prime} \mathrm{UTR}\right)$ sequences of SARS-CoV-2 viral RNAs, even translated more efficiently than cellular mRNAs, do not protect translational inhibition by its NSP1 [53]. Evidence of direct contact between mRNAs and the $28 \mathrm{~S}$ rRNA is still lacking but many sequence complementarities between the two have been predicted in silico [54]. The tRNAs may also bridge mRNAs to the $18 \mathrm{~S}$ rRNA via their anticodon stem-loop or to the $28 \mathrm{~S}$ rRNA via their $\mathrm{D}$ and $\mathrm{T}$ stem-loops [55].

The secondary structures of eukaryotic rRNAs, including yeast, mouse, and human $18 \mathrm{~S}, 28 \mathrm{~S} / 5.8 \mathrm{~S}$, and $5 \mathrm{~S}$ rRNAs, have been published [56-58]. Their stem-loops with corresponding nucleotides would assist in the interrogation of chimeric mRNA-rRNA sequences. In theory, $5^{\prime}$ end of mRNAs containing proper hydroxyl or phosphate group can be ligated directly or via tRNAs to $3^{\prime}$ end of the $18 \mathrm{~S}$ rRNA because interactions of mRNAs and/or 
tRNAs with the 18S rRNA have been repeatedly observed as exemplified above. The consistent base-pairing of $3^{\prime}$ end of the $5.8 \mathrm{~S}$ rRNA with $5^{\prime}$ end of the $28 \mathrm{~S}$ rRNA across species would allow proximity ligation to produce a $5.8 \mathrm{~S}-28 \mathrm{~S}$ chimera within species or in the recombinant ribosome. The direct interactions among 18S, 28S/5.8S, and 5S rRNAs, though not yet proven, may be promoted after the removal of ribosomal proteins. In addition, sitespecific endonucleases or endo-exonucleases, to fragment mRNAs and/or rRNAs [59-64], may be useful to generate multiple free $5^{\prime}$ - and $3^{\prime}$-ends for ligation. The mRNA-rRNA chimeras of hundreds or thousands of nucleotides in length may be directly interrogated by nanopore technology, described in the section below, or converted to long cDNAs by highly-processive reverse transcriptase before subsequent preparations that are compatible with long-read sequencing platforms. Alternatively, the long chimeras generated as RNAs or cDNAs may be separated individually, followed by fragmentation and library preparation with a unique barcoded adaptor for each chimera, proposed in the section below, before pooling together for pair-end reads of up to a hundred nucleotides by short-read sequencers.

\subsection{Nanopore Gating of Individual Ribosomes}

The estimated sizes of eukaryotic ribosomes range from $10 \mathrm{~nm}$ to $30 \mathrm{~nm}$ in diameter (yeast: about $15 \mathrm{~nm}$; rat dorsal ganglia: about $24 \mathrm{~nm}$; human: about $25 \mathrm{~nm}$ ) with an estimated number of ribosomes per cell of $2 \times 10^{5}$ in budding yeast, $5 \times 10^{5}$ in fission yeast, and $4 \times 10^{6}$ in HeLa cell [65-67]. The sucrose gradient ultracentrifugation, first developed in the 1960s [68,69], remains the mainstream technology to isolate ribosomes or their subunits. Other techniques, including affinity purification and size exclusion chromatography-ultrahigh pressure liquid chromatography, have also been used to shorten the time and steps of the isolation processes [70-72]. However, these methods obtain pooled ribosomes, or in some conditions, may separate monosomes from polysomes, and thus do not discriminate heterogeneous ribosomes. In order to determine the heterogeneity of ribosomes, individual ribosomes have to be separated before subsequent examinations of their rRNAs, RPs, mRNA substrate, and other translational components. One technology currently being explored as a proof-of-principle is the solid-state nanopore device.

A solid-state nanopore of $45 \mathrm{~nm}$ in diameter, etched and milled on $\mathrm{SiO}_{2} / \mathrm{Si}_{3} \mathrm{~N}_{4}$ multilayer thin film as the component of a microfluidic chip, allows a single 50S ribosomal subunit to pass through the nanopore by controlling the voltage externally applied [73]. The same team subsequently constructed a programmable nanopore-optofluidic device, containing a nanopore drilled through $\mathrm{SiO}_{2} / \mathrm{Ta}_{2} \mathrm{O}_{5}$ layers, to deliver a single $70 \mathrm{~S}$ ribosome across a $38 \mathrm{~nm}$-wide nanopore. It also can deliver a single $\lambda$-DNA across a $20 \mathrm{~nm}$-wide nanopore with a voltage feedback control for the selected number of biomolecules to translocate via the nanopore [74]. A quartz-based glass nano-pipette of $\approx 60 \mathrm{~nm}$ in diameter, produced via laser pulling, has been used to discriminate individual 805 ribosomes from polysomes according to voltage peak amplitude and particle dwell time [75]. These nanopore technologies provide great potential to obtain individual ribosomes for subsequent RNA and protein characterizations.

\subsection{Nanopore RNA Sequencing and/or Structural Analyses}

As discussed above, rRNA sequence variations and post-transcriptional modifications, as well as engagement of $\mathrm{tRNAs}$, contribute to the heterogeneity of ribosomes. A long-read sequencing platform is needed to interrogate hundreds to thousands of nucleotides in length. The nanopore technology provides such long-read capability and direct RNA sequencing without cDNA synthesis and PCR amplification steps, which are required in shortread sequencing protocols. The Oxford Nanopore Technologies (ONT) first demonstrates a direct RNA read length of over 1500-nucleotide yeast transcripts with $>90 \%$ accuracy and with the ability to detect RNA modifications, including N6-methyladenosine (m6A) and 5-methylcytosine (5-mC), using the MinION R9.4 flowcell [76]. The ONT utilizes an array of protein nanopores and provides kits and software to conduct the entire sequencing 
process. The newer R9.4.1 flowcell has been used to identify pseudouridine ( $\Psi)$, an isomer of uridine (U), in SARS-CoV-2 RNA by analyzing ionic current and dwell time data [77]. A full-length of $\approx 1.5 \mathrm{~kb}$ E. coli $16 \mathrm{~S}$ rRNA sequence, 7-methylguanosine and pseudouridine modifications, and single nucleotide variants among $7 \mathrm{rRNA}$ copies have been also detected using FLO-MIN106 SpotON flowcell from the ONT [78]. A protocol to sequence human $18 \mathrm{~S}, 28 \mathrm{~S}, 5,8 \mathrm{~S}$, and $5 \mathrm{~S}$ rRNAs based on the MinION platform was also developed to produce a high-sequencing output of over four thousand sequence reads on each rRNA [79].

In addition to sequencing analyses, RNA secondary or tertiary structures with or without chemical modifications are also detectable by nanopore technology. The RNA structure analysis using the nanopore sequencing (abbreviated as PORE-cupine) method, which applies the MinION flowcell to sequence chemically modified RNAs, demonstrated the feasibility to reproduce RNA secondary structures, including protein-binding sites from established short-read sequencing analyses of RNAs modified by the same chemicals [80]. This PORE-cupine method is also able to decipher the structures of thousands of coding genes, noncoding genes (including four cytosolic rRNAs), and pseudogenes along with the identification of two or more single-nucleotide variants in 90 transcripts across the hESC transcriptome. This provides a fast global view of RNA-RNA and RNA-protein interactions. Methodologies capable of capturing native tertiary RNA structures have been explored by other nanopore technologies using different pore systems. $\mathrm{A} \mathrm{Si}_{3} \mathrm{~N}_{4}$-nanopore of $\approx 3 \mathrm{~nm}$ in diameter was used to differentiate 5 tRNA species, which are critical partners for ensuring translational fidelity by ribosome. This is according to characteristic dwell time and current blockade level after analyses by an optimized machine learning algorithm [81]. Modeling of pseudoknot folding kinetics was carried out for a known RNA sequence captured on an $\alpha$-hemolysin protein nanopore [82], potentially for validating the impact of sequence variant to RNA tertiary structure. The dual characteristics of a large vestibule $(\approx 4.8 \mathrm{~nm})$ and the narrow constriction $(\approx 1.2 \mathrm{~nm})$ of a Mycobacterium smegmatis porin A (MspA) have been utilized to construct a nanopore for determinations of RNA tertiary structure and sequence in a single molecule through trapping and translocation [83]. The MspA-nanopore can make a distinction among microRNA (22-nt double strand), small interfering RNA (21-nt double strand), tRNA (76 nt), and 5S rRNA (120 nt) based on electric current fluctuations between trapping and translocation processed by a machine learning algorithm. A $23 \mathrm{~S}$ rRNA (2904 nt) and a 16S rRNA (1542 nt) have been also tested in this nanopore system but their trapping and translocation characteristics are less defined and require further optimization.

\subsection{Single-ribosome Mass Spectrometry}

The possibility to identify individual ribosomal proteins, some containing posttranslational modifications, of an intact ribosome by mass spectrometry has been demonstrated in E. coli $70 \mathrm{~S}$ ribosome, and its $30 \mathrm{~S}$ and $50 \mathrm{~S}$ subunits, through a controlled dissociation by manipulating the energy of gas-phase collision [84]. However, the broadening of mass/charge $(\mathrm{m} / \mathrm{z})$ peaks, likely contributed by ions from the buffer solution and protein-free RNA, affects the accuracy of ribosome mass determination and the resolution of individual ribosomal proteins. An ultra-high mass range spectrometry, developed to enhance the detection of high $m / z$ ions, improves the accuracies of mass measurements for the intact or native E. coli 70S, 30S, and 50S ribosomes. It further identifies multiple populations of a $30 \mathrm{~S}$ or $50 \mathrm{~S}$ subunit as a result of stoichiometric differences in ribosomal proteins and/or the presence of transient ribosome-interacting proteins, confirming the notion of ribosomal heterogeneity [85]. The same research group also incorporated charge detection mass spectrometry (CDMS) into the commercial Orbitrap mass analyzer to simultaneously determine the $\mathbf{z}$ and $m / z$ of individual ions. It also demonstrated a high accuracy of assigning masses to native human $80 \mathrm{~S}, 40 \mathrm{~S}$, and $60 \mathrm{~S}$ ribosomes and high resolution for detecting heterogeneity of ribosomes using the Orbitrap-based CDMS [86]. Since mass spectrometry requires a sufficient number (for example, $10^{3}$ to $10^{5}$ ) of single ion events to obtain overlapping series of peaks, the ribosome concentrations of 0.1 to $5 \mu \mathrm{M}$ (equivalent 
to about $6 \times 10^{16}$ to $3 \times 10^{18}$ ribosomes) used in the above mass spectrometry methodologies add more layers of complexity to differentiate heterogeneous ribosomes from a large pool of ribosomes.

\subsection{Microfluidic Droplets for Separating Ribosomes or Indexing rRNAs/mRNAs}

Since the heterogeneity of ribosomes arises from the individuality of each ribosome or ribosomal population, examinations of a large number of translating ribosomes separately may provide a solution for matching a sequence signature of the mRNA or translated peptide to a specific ribosome or ribosomal population. To provide such a solution, several microfluidic devices, capable of sorting functionalized magnetic beads or generating droplets via micrometer-scale channels to encapsulate enzymatic reagents, are discussed or proposed. One microfluidic device has been conceptualized to lyse cells in the microfluidic channel, followed by capturing translating ribosomes by magnetic particles covalently attached with oligonucleotides. This is complementary to a specific mRNA or attached with antibodies against a specific ribosomal protein, and separating as well as sorting the bound ribosomes for downstream analyses [87]. A microfluidic capillary device has been manufactured to generate water-oil-water, double-emulsion droplets that encapsulate ribosomes and reagents for translating a membrane protein inside the droplets [88]. Ligation of cDNAs with unique adaptors containing a specific sequence barcode or index inside a droplet is achievable in many commercially available microfluidic droplet generators. A single-cell combinatorial fluidic indexing (scifi) is further developed to maximize the usage of reagents [89]. Each droplet houses unique adaptors and encapsulates one or a few pre-indexed cells or nuclei while traveling through the micrometer channel of the microfluidic droplet generator. Inside the droplet, cDNAs, which are synthesized in permeabilized cells or nuclei using a pre-indexed primer, are released from the single or the few cells or nuclei and are subsequently ligated with the barcoded or indexed adaptors. Thousands to millions of cells or nuclei are processed enzymatically inside corresponding thousands to millions of droplets. Barcode-tagged cDNAs are then pooled for library preparation and high-throughput sequencing. The sequencing data from the same barcode represent a single-cell RNA profile. In theory, the cells or nuclei can be substituted with ribosomes and the scifi protocol can be modified to ligate rRNAs and mRNAs with unique adaptors for each ribosome inside a droplet and to sequence a pool of barcoded rRNAs and mRNAs. In this case, rRNAs and corresponding mRNA substrate from the same translating ribosome would be identified by the presence of the same barcode.

\section{Final Notes}

Several strategies to differentiate heterogeneous ribosomes, or to identify specialized ribosomes with their mRNA substrates, are discussed to assist in developing assays for clinical study. The above-exemplified methodologies do not appear to be readily applicable to or to be currently used in the testing of clinical samples. To determine the role of ribosomal heterogeneity in COVID-19-related pathological characteristics, examination of clinical samples is needed. The key obstacle of converting research tools for clinical use is the capability to analyze a tiny amount of patients' samples. Preferably, an assay should be able to obtain test results from a clinical sample with a quantity at nano- or micro-scale. Since the respiratory system is the major route of SARS-CoV-2 viral entry, nasal or nasopharyngeal swab, or bronchial lavage, is commonly performed. It would provide a sufficient number of ribosomes, estimated to be millions per cell, for assays that have a sensitivity to detect a single ribosome. Chemical or UV fixation is required for samples collected from COVID-19 patients to inactivate the virus. Some crosslinking agents described in the chemical probing section above have been routinely used to fix cells or tissues in the clinical laboratory. Samples from healthy patients may not require fixation if they are immediately analyzed. Integration of different technologies into a central location or a community of close vicinity would facilitate the sample processing and data collection plus computation. Careful design of a clinical trial to recruit a sufficient number 
of participants is essential to reach statistical power in multivariate analyses. Comorbidity of COVID-19 with chronic diseases is a frequent clinical manifestation in severe cases. The study of ribosomal heterogeneity in COVID-19 patients may also shed light on other diseases. The process to develop a clinical protocol for examining the role of ribosomal heterogeneity in COVID-19 patients is a challenging task and requires joint efforts from multidisciplinary areas. A general strategy is proposed here, and a schematic approach is outlined in Figure 1. This article is intended to foster discussions among researchers and clinicians for a better understanding of the current pandemic or better preparation for the next pandemic. The assays to identify specialized ribosomes, along with their corresponding mRNA transcripts and/or peptides, are also applicable to study other diseases.
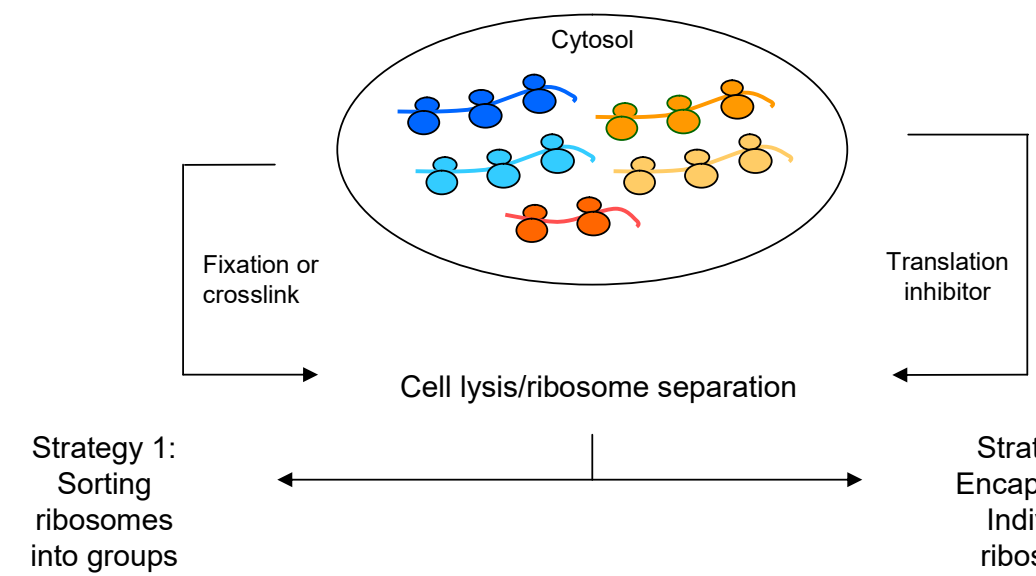

Strategy 2:

Encapsulating

Individual

ribosomes
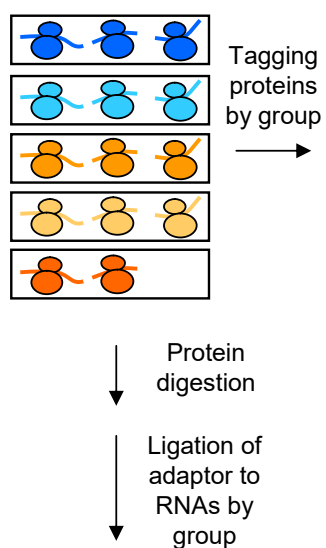

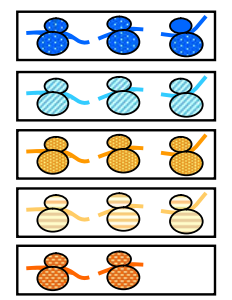

88
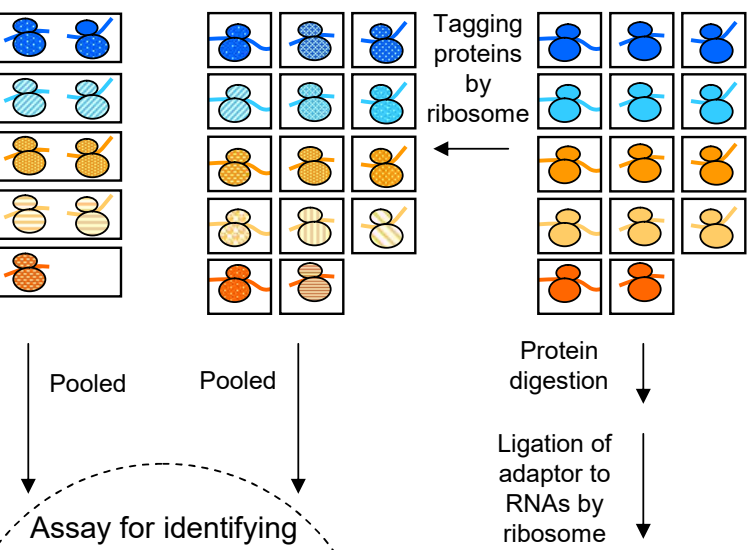
proteins and peptides
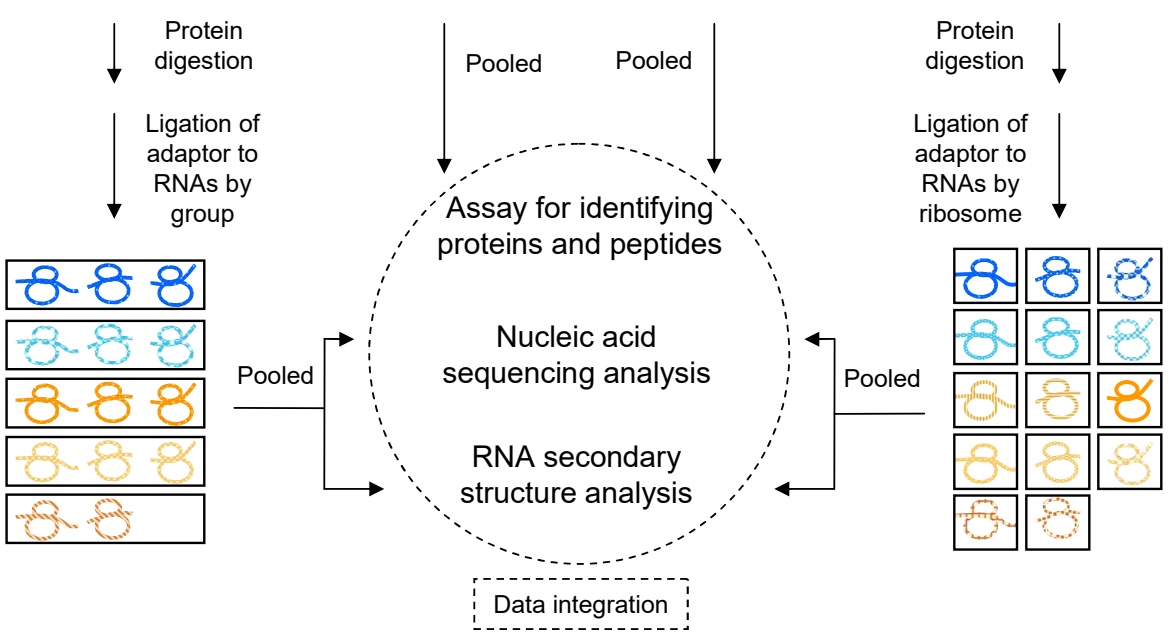

Figure 1. A general strategy for developing a protocol to characterize heterogeneous ribosomes by group or by ribosome. Heterogeneous ribosomes are colored differently, and active ribosomes, containing their corresponding mRNAs and/or translated peptides, can be separated by sorting into groups or by encapsulating individual ribosomes. The sorting may be achieved by solid-phase isolation according to unique protein and/or RNA properties, such as specific ribosomal proteins, translational cofactors, mRNAs, and translated peptides. This would be followed by transferring the 
solid-phase captured ribosomes into different compartments of a micro- or nano-plate. Nanoporeequipped, microfluidic, droplet-generating devices are suitable for encapsulating ribosomes individually. Protein or peptide components of the ribosomes can be tagged using reactions, such as by click chemistry [90], by ribosome group after sorting, or by an individual ribosome after encapsulation. Tagged ribosomes are then pooled for protein analyses, such as mass spectrometry, to obtain the identities of protein or peptide components, and the origins of heterogeneous ribosomes can be traced after decoding their unique tags. An aliquot of the sorted ribosomes from the same compartment or of the encapsulated ribosomes can be processed, for example, by extraction or protein digestion, to acquire suitable RNAs for subsequent adaptor ligation. The ligation step may also generate rRNA-mRNA chimeras that are useful for analyses of RNA secondary structures and validation of rRNA-mRNA pairs. For crosslinked RNAs, a reversal step is required to break the crosslink before downstream enzymatic steps in preparation of RNAs, cDNAs, or PCR-amplified products for nucleic acid sequencing. Each adaptor contains a unique barcode or index sequence that is used to identify the origin of rRNAs and mRNAs within the same group of or within the individual ribosome. The identities of translated peptides from protein analyses can then be integrated with mRNA sequence analyses to find the origins of the groups of or individual active ribosomes and to differentiate heterogeneous ribosomes.

Author Contributions: Conceptualization, Y.-H.S.; writing-original draft preparation, Y.-H.S.; writing-review and editing, Y.-H.S. All authors have read and agreed to the published version of the manuscript.

Funding: Not applicable.

Institutional Review Board Statement: Not applicable.

Informed Consent Statement: Not applicable.

Data Availability Statement: Not applicable.

Acknowledgments: Not applicable.

Conflicts of Interest: The authors declare no conflict of interest. The views expressed do not necessarily represent those of the US Federal agency.

\section{References}

1. Simeoni, M.; Cavinato, T.; Rodriguez, D.; Gatfield, D. I(nsp1)ecting SARS-CoV-2-ribosome interactions. Commun. Biol. 2021, 4, 715. [CrossRef]

2. V'kovski, P.; Kratzel, A.; Steiner, S.; Stalder, H.; Thiel, V. Coronavirus biology and replication: Implications for SARS-CoV-2. Nat. Rev. Microbiol. 2021, 19, 155-170. [CrossRef]

3. Wong, J.P.; Damania, B. SARS-CoV-2 dependence on host pathways. Science 2021, 371, 884-885. [CrossRef] [PubMed]

4. Banerjee, A.K.; Blanco, M.R.; Bruce, E.A.; Honson, D.D.; Chen, L.M.; Chow, A.; Bhat, P.; Ollikainen, N.; Quinodoz, S.A.; Loney, C.; et al. SARS-CoV-2 disrupts splicing, translation, and protein trafficking to suppress host defenses. Cell 2020, 183, 1325-1339. [CrossRef] [PubMed]

5. Finkel, Y.; Avi, G.A.; Nachshon, A.; Winkler, R.; Fisher, T.; Rozman, B.; Mizrahi, O.; Lubelsky, Y.; Zuckerman, B.; Slobodin, B.; et al. SARS-CoV-2 uses a multipronged strategy to impede host protein synthesis. Nature 2021, 594, 240-245. [CrossRef] [PubMed]

6. Lapointea, C.P.; Groselya, R.; Johnsona, A.G.; Wanga, J.; Fernándezc, I.S.; Puglisi, J.D. Dynamic competition between SARS-CoV-2 NSP1 and mRNA on the human ribosome inhibits translation initiation. Proc. Natl. Acad. Sci. USA 2021, 118, e2017715118. [CrossRef] [PubMed]

7. Flynn, R.A.; Belk, J.A.; Qi, Y.; Yasumoto, Y.; Wei, J.; Alfajaro, M.M.; Shi, Q.; Mumbach, M.R.; Limaye, A.; DeWeirdt, P.C.; et al. Discovery and functional interrogation of SARS-CoV-2 RNA-host protein interactions. Cell 2021, 184, 2394-2411. [CrossRef]

8. Labeau, A.; Lefevre-Utile, A.; Bonnet-Madin, L.; Fery-Simonian, L.; Soumelis, V.; Lotteau, V.; Vidalain, P.-O.; Amara, A.; Meertens, L. Characterization and functional interrogation of 1 SARS-CoV-2 RNA interactome. bioRxiv 2021.

9. Lee, S.; Lee, Y.-S.; Choi, Y.; Son, A.; Park, Y.; Lee, K.-M.; Kim, J.; Kim, J.-S.; Kim, V.N. The SARS-CoV-2 RNA interactome. Mol. Cell 2021, 81, 2838-2850. [CrossRef]

10. Schmidt, N.; Lareau, C.A.; Keshishian, H.; Ganskih, S.; Schneider, C.; Hennig, T.; Melanson, R.; Werner, S.; Wei, Y.; Zimmer, M.; et al. The SARS-CoV-2 RNA-protein interactome in infected human cells. Nat. Microbiol. 2021, 6, 339-353. [CrossRef]

11. Bhatt, P.R.; Scaiola, A.; Loughran, G.; Leibundgut, M.; Kratzel, A.; Meurs, R.; Dreos, R.; O'Connor, K.M.; McMillan, A.; Bode, J.W.; et al. Structural basis of ribosomal frameshifting during translation of the SARS-CoV-2 RNA genome. Science 2021, 372, 1306-1313. [CrossRef] [PubMed] 
12. Ziv, O.; Price, J.; Shalamova, L.; Kamenova, T.; Goodfellow, I.; Weber, F.; Miska, E.A. The short-and long-range RNA-RNA Interactome of SARS-CoV-2. Mol. Cell 2020, 80, 1067-1077. [CrossRef] [PubMed]

13. Cao, C.; Cai, Z.; Xiao, X.; Rao, J.; Chen, J.; Hu, N.; Yang, M.; Xing, X.; Wang, Y.; Li, M.; et al. The architecture of the SARS-CoV-2 RNA genome inside virion. Nat. Commun. 2021, 12, 3917. [CrossRef] [PubMed]

14. Basu, A.; Penumutchu, S.; Nguyen, K.; Mbonye, U.; Tolbert, B.S.; Karn, J.; Komar, A.A.; Mazumder, B. A structurally conserved RNA element within SARS-CoV-2 ORF1a RNA and S mRNA regulates translation in response to viral S protein-induced signaling in human lung cells. J. Virol. 2021, 96, 1. [CrossRef] [PubMed]

15. Kamel, W.; Noerenberg, M.; Cerikan, B.; Chen, H.; Jarvelin, A.I.; Kammoun, M.; Lee, J.Y.; Shuai, N.; Garcia-Moreno, M.; Andrejeva, A.; et al. Global analysis of protein-RNA interactions in SARS-CoV-2-infected cells reveals key regulators of infection. Mol. Cell 2021, 81, 2851-2867. [CrossRef] [PubMed]

16. Wang, B.; Svetlov, V.; Wolf, Y.I.; Koonin, E.V.; Nudler, E.; Artsimovitch, I. Allosteric activation of SARS-CoV-2 RNA-dependent RNA polymerase by remdesivir triphosphate and other phosphorylated nucleotides. mBio 2021, 12, 1. [CrossRef] [PubMed]

17. Ferretti, M.B.; Ghalei, H.; Ward, E.A.; Potts, E.L.; Karbstein, K. Rps26 directs mRNA-specific translation by recognition of Kozak sequence elements. Nat. Struct. Mol. Biol. 2017, 24, 700-707. [CrossRef]

18. Sample, P.J.; Wang, B.; Reid, D.W.; Presnyak, V.; McFadyen, I.; Morris, D.R.; Seelig, G. Human 5'UTR design and variant effect prediction from a massively parallel translation assay. Nat. Biotechnol. 2019, 37, 803-809. [CrossRef]

19. Shi, Z.; Fujii, K.; Kovary, K.M.; Genuth, N.R.; Rost, H.L.; Teruel, M.N.; Barna, M. Heterogeneous ribosomes preferentially translate distinct subpools of mRNAs genome-wide. Mol. Cell 2017, 67, 71-83. [CrossRef]

20. Simsek, D.; Tiu, G.C.; Flynn, R.A.; Byeon, G.W.; Leppek, K.; Xu, A.F.; Chang, H.Y.; Barna, M. The mammalian ribo-interactome reveals ribosome functional diversity and heterogeneity. Cell 2017, 169, 1051-1065. [CrossRef]

21. Leppek, K.; Byeon, G.W.; Fujii, K.; Barna, M. VELCRO-IP RNA-seq reveals ribosome expansion segment function in translation genome-wide. Cell Rep. 2021, 34, 108629. [CrossRef] [PubMed]

22. Locati, M.D.; Pagano, J.F.B.; Girard, G.; Ensink, W.A.; van Olst, M.; van Leeuwen, S.; Nehrdich, U.; Spaink, H.P.; Rauwerda, H.; Jonker, M.J.; et al. Expression of distinct maternal and somatic 5.8S, 18S, and 28S rRNA types during zebrafish development. RNA 2017, 28, 1188-1199. [CrossRef] [PubMed]

23. Li, D.; Wang, J. Ribosome heterogeneity in stem cells and development. J. Cell Biol. 2020, 219, e202001108. [CrossRef] [PubMed]

24. Gay, D.M.; Lund, A.H.; Jansson, M.D. Translational control through ribosome heterogeneity and functional specialization. Trends Biochem. Sci. 2022, 47, 66-81. [CrossRef]

25. Aw, J.G.A.; Shen, Y.; Wilm, A.; Sun, M.; Lim, X.N.; Boon, K.-L.; Tapsin, S.; Chan, Y.-S.; Tan, C.-P.; Sim, A.Y.L.; et al. In Vivo mapping of eukaryotic RNA interactomes reveals principles of higher-order organization and regulation. Mol. Cell 2016, 62, 603-617. [CrossRef]

26. Ziv, O.; Gabryelska, M.M.; Lun, A.T.L.; Gebert, L.F.R.; Sheu-Gruttadauria, J.; Meredith, L.W.; Liu, Z.-Y.; Kwok, C.K.; Qin, C.-F.; MacRae, I.J.; et al. COMRADES determines in vivo RNA structures and interactions. Nat. Methods 2018, 15, 785-788. [CrossRef]

27. Christy, T.W.; Giannetti, C.A.; Laederach, A.; Weeks, K.M. Identifying proximal RNA interactions from cDNA-encoded crosslinks with ShapeJumper. PLoS Comput. Biol. 2021, 17, e1009632. [CrossRef]

28. Sharma, E.; Sterne-Weiler, T.; O'Hanlon, D.; Blencowe, B.J. Global mapping of human RNA-RNA interactions. Mol. Cell 2016, 62, 618-626. [CrossRef] [PubMed]

29. Sugimoto, Y.; Vigilante, A.; Darbo, E.; Zirra, A.; Militti, C.; D'Ambrogio, A.; Luscombe, N.M.; Ule, J. hiCLIP reveals the in vivo atlas of mRNA secondary structures recognized by Staufen 1. Nature 2015, 519, 491-494. [CrossRef]

30. Tüting, C.; Iacobucci, C.; Ihling, C.H.; Kastritis1, P.L.; Sinz, A. Structural analysis of $70 S$ ribosomes by cross-linking/mass spectrometry reveals conformational plasticity. Sci. Rep. 2020, 10, 12618. [CrossRef]

31. Urdaneta, E.C.; Vieira-Vieira, C.H.; Hick, T.; Wessels, H.-H.; Figini, D.; Moschall, R.; Medenbach, J.; Ohler, U.; Granneman, S.; Selbach, M.; et al. Purification of cross-linked RNA-protein complexes by phenol-toluol extraction. Nat. Commun. 2019, 10, 990. [CrossRef]

32. Velema, W.A.; Park, H.S.; Kadina, A.; Orbai, L.; Kool, E.T. Trapping transient RNA complexes by chemically reversible acylation. Angew. Chem. Int. Ed. 2020, 59, 22017-22022. [CrossRef] [PubMed]

33. Zhang, M.; Li, K.; Bai, J.; Velema, W.A.; Yu, C.; van Damme, R.; Lee, W.H.; Corpuz, M.L.; Chen, J.-F.; Lu, Z. Optimized photochemistry enables efficient analysis of dynamic RNA structuromes and interactomes in genetic and infectious diseases. Nat. Commun. 2021, 12, 2344. [CrossRef] [PubMed]

34. Kudla, G.; Granneman, S.; Hahn, D.; Beggs, J.D.; Tollervey, D. Cross-linking, ligation, and sequencing of hybrids reveals RNA-RNA interactions in yeast. Proc. Natl. Acad. Sci. USA 2011, 108, 10010-10015. [CrossRef] [PubMed]

35. Trendel, J.; Schwarz, T.; Horos, R.; Prakash, A.; Bateman, A.; Hentze, M.W.; Krijgsveld, J. The human RNA-binding proteome and its dynamics during translational arrest. Cell 2019, 176, 391-403. [CrossRef] [PubMed]

36. Cai, Z.; Cao, C.; Ji, L.; Ye, R.; Wang, D.; Xia, C.; Wang, S.; Du, Z.; Hu, N.; Yu, X.; et al. RIC-seq for global in situ profiling of RNA-RNA spatial interactions. Nature 2020, 582, 432-437. [CrossRef]

37. Slavin, M.; Zamel, J.; Zohar, K.; Eliyahu, T.; Braitbard, M.; Brielle, E.; Baraz, L.; Stolovich-Rain, M.; Friedman, A.; Wolf, D.G.; et al. Targeted in situ cross-linking mass spectrometry and integrative modeling reveal the architectures of three proteins from SARS-CoV-2. Proc. Natl. Acad. Sci. USA 2021, 118, e2103554118. [CrossRef] 
38. Kudla, G.; Wan, Y.; Helwak, A. RNA Conformation Capture by Proximity Ligation. Annu. Rev. Genom. Hum. Genet. 2020, 21, 81-100. [CrossRef]

39. Lu, Z.; Chang, H.Y. The RNA base-pairing problem and base-pairing solutions. Cold Spring Harb. Perspect. Biol. 2018, 10, a034926. [CrossRef]

40. Qian, X.; Zhao, J.; Yeung, P.Y.; Zhang, Q.C.; Kwok, C.K. Revealing lncRNA structures and interactions by sequencing-based approaches. Trends Biochem. Sci. 2019, 44, 33-52. [CrossRef]

41. Nguyen, T.C.; Zaleta-Rivera, K.; Huang, X.; Dai, X.; Zhong, S. RNA, action through interactions. Trends Genet. 2018, 34, 867-882 [CrossRef]

42. Wheeler, E.C.; Van Nostrand, E.L.; Yeo, G.W. Advances and challenges in the detection of transcriptome-wide protein-RNA interactions. WIREs RNA 2018, 9, e1436. [CrossRef] [PubMed]

43. Mitchell, D., III; Assmann, S.M.; Bevilacqua, P.C. Probing RNA structure in vivo. Curr. Opin. Struct. Biol. 2019, 59, 151-158 [CrossRef]

44. Granneman, S.; Kudla, G.; Petfalski, E.; Tollervey, D. Identification of protein binding sites on U3 snoRNA and pre-rRNA by UV cross-linking and high-throughput analysis of cDNAs. Proc. Natl. Acad. Sci. USA 2009, 106, 9613-9618. [CrossRef]

45. Ramani, V.; Qiu, R.; Shendure, J. High-throughput determination of RNA structure by proximity ligation. Nat. Biotechnol. 2015, 33, 980-984. [CrossRef] [PubMed]

46. Panopoulos, P.; Mauro, V.P. Antisense masking reveals contributions of mRNA-rRNA base pairing to translation of Gtx and FGF2 mRNAs. J. Biol. Chem. 2008, 283, 33087-33093. [CrossRef] [PubMed]

47. Meng, Z.; Jackson, N.L.; Shcherbakov, O.D.; Choi, H.; Blume, S.W. The human IGF1R IRES likely operates through a ShineDalgarno-like interaction with the G961 loop (E-site) of the 18S rRNA and is kinetically modulated by a naturally polymorphic polyU loop. J. Cell Biochem. 2010, 110, 531-544.

48. Martin, F.; Menetret, J.-F.; Simonetti, A.; Myasnikov, A.G.; Vicens, Q.; Prongidi-Fix, L.; Natchiar, S.K.; Klaholz, B.P.; Eriani, G. Ribosomal 18S rRNA base pairs with mRNA during eukaryotic translation initiation. Nat. Commun. 2016, 7, 12622. [CrossRef]

49. Matsuda, D.; Mauro, V.P. Base pairing between hepatitis $C$ virus RNA and $18 \mathrm{~S}$ rRNA is required for IRES-dependent translation initiation in vivo. Proc. Natl. Acad. Sci. USA 2014, 111, 15385-15389. [CrossRef]

50. Leppek, K.; Fujii, K.; Quade, N.; Susanto, T.T.; Boehringer, D.; Lenarcic, T.; Xue, S.; Genuth, N.R.; Ban, N.; Barna, M. Gene- and species-specific hox mRNA translation by ribosome expansion segments. Mol. Cell 2020, 80, 980-995. [CrossRef]

51. Wang, J.; Wang, J.; Shin, B.-S.; Kim, J.-R.; Dever, T.E.; Puglisi, J.D.; Fernández, I.S. Structural basis for the transition from translation initiation to elongation by an 80S-eIF5B complex. Nat. Commun. 2020, 11, 5003. [CrossRef] [PubMed]

52. Miao, Z.; Tidu, A.; Eriani, G.; Martin, F. Secondary structure of the SARS-CoV-2 5'-UTR. RNA Biol. 2021, 18, 447-456. [CrossRef] [PubMed]

53. Schubert, K.; Karousis, E.D.; Jomaa, A.; Scaiola, A.; Echeverria, B.; Gurzeler, L.A.; Leibundgut, M.; Thie, V.; Mühlemann, O.; Ban, N. SARS-CoV-2 Nsp1 binds the ribosomal mRNA channel to inhibit translation. Nat. Struct. Mol. Biol. 2020, 27, 959-966. [CrossRef] [PubMed]

54. Parker, M.S.; Balasubramaniam, A.; Sallee, F.R.; Parker, S.L. The expansion segments of 28S Ribosomal RNA extensively match human messenger RNAs. Front. Genet. 2018, 9, 66. [CrossRef]

55. Bastide, A.; David, A. Interaction of rRNA with mRNA and tRNA in translating mammalian ribosome: Functional implications in health and disease. Biomolecules 2018, 8, 100. [CrossRef]

56. Armachea, J.-P.; Jarascha, A.; Angera, A.M.; Villab, E.; Beckera, T.; Bhushana, S.; Jossinetc, F.; Habeckd, M.; Dindara, G.; Franckenberga, S.; et al. Cryo-EM structure and rRNA model of a translating eukaryotic $80 \mathrm{~S}$ ribosome at 5.5-Å resolution. Proc. Natl. Acad. Sci. USA 2010, 107, 19748-19753. [CrossRef] [PubMed]

57. Holmberg, L.; Melander, Y.; Nygard, O. Probing the structure of mouse Ehrlich ascites cell 5.8S, $18 \mathrm{~S}$ and 28S ribosomal RNA in situ. Nucleic Acids Res. 1994, 22, 1374-1382. [CrossRef] [PubMed]

58. Anger, A.M.; Armache, J.-P.; Berninghausen, O.; Habeck, M.; Subklewe, M.; Wilson, D.N.; Beckmann, R. Structures of the human and Drosophila $80 \mathrm{~S}$ ribosome. Nature 2013, 497, 80-85. [CrossRef]

59. Holmberg, L.; Nygard, O. Mapping of nuclease-sensitive sites in native reticulocyte ribosomes: An analysis of the accessibility of ribosomal RNA to enzymatic cleavage. Eur. J. Biochem. 1997, 247, 160-168. [CrossRef]

60. Culviner, P.H.; Nocedal, I.; Fortune, S.M.; Laub, M.T. Global analysis of the specificities and targets of endoribonucleases from Escherichia coli toxin-antitoxin systems. Mbio 2021, 12, 1. [CrossRef]

61. Han, Y.; Lee, E.-J. Substrate specificity of bacterial endoribonuclease toxins. BMB Rep. 2020, 53, 611-621. [CrossRef]

62. Masuda, H.; Inouye, M. Toxins of prokaryotic toxin-antitoxin systems with sequence-specific endoribonuclease activity. Toxins 2017, 9, 140. [CrossRef] [PubMed]

63. Pedersen, K.; Zavialov, A.V.; Pavlov, M.Y.; Elf, J.; Gerdes, K.; Ehrenberg, M. the bacterial toxin rele displays codon-specific cleavage of mRNAs in the ribosomal a site. Cell 2003, 112, 131-140. [CrossRef]

64. Querido, J.B.; Sokabe, M.; Kraatz, S.; Gordiyenko, Y.; Skehel, J.M.; Fraser, C.S.; Ramakrishnan, V. Structure of a human 48S translational initiation complex. Science 2020, 369, 1220-1227. [CrossRef] [PubMed]

65. MacLean, N. Ribosome numbers in a fission yeast. Nature 1965, 207, 322-323. [CrossRef] [PubMed]

66. Zelena, J. Ribosomes in myelinated axons of dorsal root ganglia. Z. Zellforsch. Microsk. Anat. 1972, 124, 217-229. [CrossRef] [PubMed] 
67. Turowski, T.W.; Tollervey, D. Cotranscriptional events in eukaryotic ribosome synthesis. WIREs RNA 2015, 6, 129-139. [CrossRef]

68. Britten, R.J.; Roberts, R.B. High-resolution density gradient sedimentation analysis. Science 1960, 131, 32-33. [CrossRef]

69. Warner, J.R.; Knopf, P.M.; Rich, A. A multiple ribosomal structure in protein synthesis. Proc. Natl. Acad. Sci. 1963, 49, 122-129. [CrossRef]

70. Heiman, M.; Kulicke, R.; Fenster, R.J.; Greengard, P.; Heintz, N. Cell type-specific mRNA purification by translating ribosome affinity purification (TRAP). Nat. Protocols 2014, 9, 1282-1291. [CrossRef]

71. Inada, T.; Winstall, E.; Tarun, S.Z.; Yates, J.R.; Schieltz, D.; Sachs, A.B. One-step affinity purification of the yeast ribosome and its associated proteins and mRNAs. RNA 2002, 8, 948-958. [CrossRef] [PubMed]

72. Yoshikawa, H.; Larance, M.; Harney, D.J.; Sundaramoorthy, R.; Ly, T.; Owen-Hughes, T.; Lamond, A.I. Efficient analysis of mammalian polysomes in cells and tissues using Ribo Mega-SEC. Elife 2018, 7, e36530. [CrossRef] [PubMed]

73. Rudenkoa, M.I.; Holmesc, M.R.; Ermolenkob, D.N.; Luntc, E.J.; Gerhardtb, S.; Nollerb, H.F.; Deamera, D.W.; Hawkinsc, A.; Schmidt, H. Controlled gating and electrical detection of single 50S ribosomal subunits through a solid-state nanopore in a microfluidic chip. Biosens. Bioelectron. 2011, 29, 34-39. [CrossRef] [PubMed]

74. Rahman, M.; Stott, M.A.; Harrington, M.; Li, Y.; Sampad, M.J.N.; Lancaster, L.; Yuzvinsky, T.D.; Noller, H.F.; Hawkins, A.R.; Schmidt, H. On demand delivery and analysis of single molecules on a programmable nanopore-optofluidic device. Nat. Commun. 2019, 10, 3712. [CrossRef] [PubMed]

75. Raveendran, M.; Leach, A.R.; Hopes, T.; Aspden, J.L.; Actis, P. Ribosome fingerprinting with a solid-state nanopore. ACS Sens. 2020, 5, 3533-3539. [CrossRef] [PubMed]

76. Garalde, D.R.; Snell, E.A.; Jachimowicz, D.; Sipos, B.; Lloyd, J.H.; Bruce, M.; Pantic, N.; Admassu, T.; James, P.; Warland, A.; et al Highly parallel direct RN A sequencing on an array of nanopores. Nat. Methods 2018, 15, 201-206. [CrossRef] [PubMed]

77. Fleming, A.M.; Mathewson, N.J.; Manage, S.A.H.; Burrows, C.J. Nanopore dwell time analysis permits sequencing and conformational assignment of pseudouridine in SARS-CoV-2. ACS Cent. Sci. 2021, 7, 1707-1717. [CrossRef]

78. Smith, A.M.; Jain, M.; Mulroney, L.; Garalde, D.R.; Akeson, M. Reading canonical and modified nucleobases in $16 S$ ribosomal RNA using nanopore native RNA sequencing. PLoS ONE 2019, 14, e0216709. [CrossRef]

79. Jain, M.; Olsen, H.E.; Akeson, M.; Abu-Shumays, R. Adaptation of Human Ribosomal RNA for Nanopore Sequencing of Canonical and Modified Nucleotides. In RNA Modifications: Methods and Protocols, Methods in Molecular Biology; McMahon, M., Ed.; Springer Science+Business Media, LLC: New York, NY, USA, 2021; Volume 2298, pp. 53-74.

80. Aw, J.G.A.; Lim, S.W.; Wang, J.X.; Lambert, F.R.P.; Tan, W.T.; Shen, Y.; Zhang, Y.; Kaewsapsak, P.; Li, C.; Ng, S.B.; et al Determination of isoform-specific RNA structure with nanopore long reads. Nat. Biotechnol. 2021, 39, 336-346. [CrossRef]

81. Henley, R.Y.; Ashcroft, B.A.; Farrell, I.; Cooperman, B.S.; Lindsay, S.M.; Wanunu, M. Electrophoretic deformation of individual transfer rna molecules reveals their identity. Nano Lett. 2016, 16, 138-144. [CrossRef]

82. Zhang, X.; Zhang, D.; Zhao, C.; Tian, K.; Shi, R.; Du, X.; Burcke, A.J.; Wang, J.; Chen, S.-J.; Gu, L.-Q. Nanopore electric snapshots of an RNA tertiary folding pathway. Nat. Commun. 2017, 8, 1458. [CrossRef] [PubMed]

83. Wang, Y.; Guan, X.; Zhang, S.; Liu, Y.; Wang, S.; Fan, P.; Du, X.; Yan, S.; Zhang, P.; Chen, H.-Y.; et al. Structural-profiling of low molecular weight RNAs by nanopore trapping/translocation using Mycobacterium smegmatis porin A. Nat. Commun. 2021, 12, 3368. [CrossRef]

84. Rostom, A.A.; Fucini, P.; Benjamin, D.R.; Juenemann, R.; Nierhaus, K.H.; Hartl, F.U.; Dobson, C.M.; Robinson, C.V. Detection and selective dissociation of intact ribosomes in a mass spectrometer. Proc. Natl. Acad. Sci. USA 2000, 97, 5185-5190. [CrossRef] [PubMed]

85. Van de Waterbeemd, M.; Fort, K.L.; Boll, D.; Reinhardt-Szyba, M.; Routh, A.; Makarov, A.; Heck, A.J.R. High-fidelity mass analysis unveils heterogeneity in intact ribosomal particles. Nat. Methods 2017, 14, 283-286. [CrossRef] [PubMed]

86. Lai, S.-H.; Tamara, S.; Heck, A.J.R. Single-particle mass analysis of intact ribosomes by mass photometry and Orbitrap-based charge detection mass spectrometry. iScience 2021, 24, 103211. [CrossRef]

87. Wegener, M.; Ennen, I.; Walhorn, V.; Anselmetti, D.; Hütten, A.; Dietz, K.-J. Magnetic tracking of protein synthesis in microfluidic environments-Challenges and perspectives. Nanomaterials 2019, 9, 0585. [CrossRef] [PubMed]

88. Martino, C.; Kim, S.-H.; Horsfall, L.; Abbaspourrad, A.; Rosser, S.J.; Cooper, J.; Weitz, D.A. Protein expression, aggregation, and triggered release from polymersomes as artificial cell-like structures. Angew. Chem. Int. Ed. 2012, 51, 6416-6420. [CrossRef] [PubMed]

89. Datlinger, P.; Rendeiro, A.F.; Boenke, T.; Senekowitsch, M.; Krausgruber, T.; Barreca, D.; Bock, C. Ultra-high-throughput single-cell RNA sequencing and perturbation screening with combinatorial fluidic indexing. Nat. Methods 2021, 18, 635-642. [CrossRef]

90. Parker, C.G.; Pratt, M.R. Click chemistry in proteomic investigations. Cell 2020, 180, 605-632. [CrossRef] 